\title{
Communication
}

\section{Eucalyptus Amplifolia and Corymbia Torelliana in the Southeastern USA: Genetic Improvement and Potential Uses}

\author{
Donald L. Rockwood ${ }^{1, *}$, Dudley A. Huber ${ }^{2}$, Mark A. Crawford ${ }^{3}$, Phillip C. Rucks ${ }^{4}$, Elizabeth Lamb ${ }^{4}$, \\ Kyle W. Fabbro ${ }^{5}$, Patrick J. Minogue ${ }^{6}{ }^{\mathbb{D}}$, Romeo Jump ${ }^{7}$ and Gary R. Hodge ${ }^{7} \mathbb{D}$
}

check for updates

Citation: Rockwood, D.L.; Huber, D.A.; Crawford, M.A.; Rucks, P.C.; Lamb, E.; Fabbro, K.W.; Minogue, P.J.; Jump, R.; Hodge, G.R. Eucalyptus Amplifolia and Corymbia Torelliana in the Southeastern USA: Genetic Improvement and Potential Uses. Forests 2022, 13, 75. https://doi.org/ $10.3390 /$ f13010075

Academic Editor: Arndt Hampe

Received: 22 November 2021

Accepted: 28 December 2021

Published: 6 January 2022

Publisher's Note: MDPI stays neutral with regard to jurisdictional claims in published maps and institutional affiliations.

Copyright: () 2022 by the authors. Licensee MDPI, Basel, Switzerland. This article is an open access article distributed under the terms and conditions of the Creative Commons Attribution (CC BY) license (https:// creativecommons.org/licenses/by/ $4.0 /)$.
1 School of Forest, Fisheries, and Geomatics Sciences, University of Florida (UF), Gainesville, FL 32611, USA

2 Quantitative Genetics, 957 Easy Street, Toccoa, GA 30577, USA; dudley@quantitative-genetics.com

3 Loch Laurel Nursery, 2867 Carroll Ulmer Road, Valdosta, GA 31601, USA; craw142@bellsouth.net

4 Phillip Rucks Citrus Nursery (PRCN) and Florida Grown Specialties, 1697 Rucks Dairy Road, Frostproof, FL 33843, USA; phillip@rucksnursery.com (P.C.R.); beth-lamb@hotmail.com (E.L.)

5 Lykes Brothers Forestry Division, Palmdale, FL 33944, USA; kyle.fabbro@lykes.com

6 North Florida Research and Education Center, University of Florida, Quincy, FL 32351, USA; pminogue@ufl.edu

7 Camcore, Department of Forestry \& Environmental Resources, North Carolina State University, Jordan Hall Addition 3231, Raleigh, NC 27695, USA; rjump@ncsu.edu (R.J.); grh@ncsu.edu (G.R.H.)

* Correspondence: dlrock@ufl.edu

\begin{abstract}
Eucalyptus amplifolia and Corymbia torelliana genetic improvement has been conducted in the lower southeastern USA by UF and collaborators since 1980. The collective accomplishments in genetic resources and potential commercial uses are summarized. For example, fast-growing, freeze-resilient $E$. amplifolia seeds are provided by 1st and 2nd generation seedling seed orchards (SSO) and a 2nd generation clonal seed orchard (CSO), while C. torelliana seed are available from 1st and 2nd generation SSOs. Breeding values (BV) have been developed for guiding the deployment of improved genotypes. Collaborative genetic improvement of these species is ongoing, including testing E. amplifolia in 11 countries and development of hybrid clones. Short Rotation Woody Crop (SRWC) systems may increase productivity and extend uses beyond conventional mulchwood to products such as medium density fiberboard (MDF), biochar, and energywood, while other possible applications include honey production, windbreaks, dendroremediation, and carbon sequestration. C. torelliana may be paired with $E$. grandis in two-row windbreaks to maximum windbreak effectiveness and may sequester as much carbon as E. grandis.
\end{abstract}

Keywords: E. amplifolia; C. torelliana; seed orchards; short rotation woody crops; biochar; carbon sequestration; Florida

\section{Introduction}

Most Eucalyptus plantings in Florida before 1970 were windbreaks, ornamentals, and shade trees in central and southern Florida [1]. Reevaluation of a number of species starting in the 1970s [2,3] included tree improvement efforts with E. amplifolia and C. torelliana (formerly E. torelliana), which had been considered of limited potential and still are minimally deployed. For both, the starting germplasm was derived from seed or trees resulting from earlier screening efforts, which resulted in the Florida Division of Forestry retaining and growing small quantities of E. amplifolia and C. torelliana for ornamental purposes.

Matching E. amplifolia and C. torelliana to the lower southeastern USA's diverse weather and soils is challenging. Climatic regions based on average low temperatures or numbers of freezes provide some broad guidelines, but freeze aberrations [4] and extended cold periods impact their freeze susceptibility at young ages. Unpredictable, extended dry spells make Florida's summer rainfall climate difficult for successful planting and early growth. Within climatic regions, soils available for planting E. amplifolia and C. torelliana can range from sandy and infertile to heavy clay to limestone to organic. 
Broad climatic regions guide the deployment of E. amplifolia and C. torelliana in Florida (Figure 1). Typically tolerant of the colder winters of northern Florida and similar regions, E. amplifolia requires good fertility with $\mathrm{pH}>5.6$, unless infertile, poorly drained soils are amended. From southern into central Florida, C. torelliana tolerates typical winter conditions and grows well across sites, especially when irrigated on deep sands.

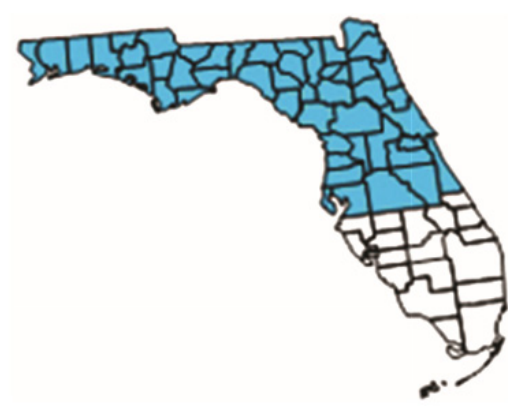

(a)

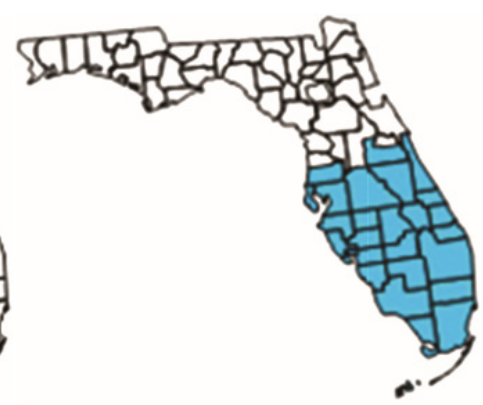

(b)

Figure 1. Planting regions in Florida for E. amplifolia (a) and C. torelliana (b) from [5].

This paper expands previous reviews [6,7] by compiling tree improvement and utilization research with E. amplifolia and C. torelliana through 2021. It highlights genetic resources, describes current and future uses, identifies ongoing research activities and needs, and acknowledges significant collaborators in this research.

\section{Genetic Resources}

The tree improvement strategy followed for E. grandis in Florida was used in developing SSOs of these two species [1,6-9]. This inexpensive, effective strategy utilized short generation time of about four years and rapid growth to concurrently test provenances, progenies, and new, primarily single-tree accessions in one place, followed by early selection and use of pedigrees to minimize inbreeding and achieve rapid genetic gains.

Two generations of E. amplifolia orchards (Table 1) produce seed for freeze-frequent northern Florida and similar areas. The 1st generation genetic base population included many new accessions, particularly individual tree accessions from frost frequent portions of the natural distribution of E. amplifolia subsp. amplifolia. Most of those accessions were retained in AO92. Two 2nd generation SSOs (AO03 and AO10) included seedlings from AO92, but were mostly composed of additional new accessions. CSO AO13 was established beginning in 2013. AO03, AO10, and AO13 can supply commercial seed for central Florida northward into southern Georgia, Alabama, Mississippi, Louisiana, and Texas based on BVs calculated from progeny tests established since 1998.

The 2008 C. torelliana genetic base population (Table 1) included 960 trees from 29 trees in windbreaks in Florida. This tropical species has demonstrated tolerance to freezing temperatures, and all 69 trees in TO08 combine freeze tolerance with good growth and tree form. Twenty-five new Australian accessions were included in the 2nd generation base population that became TO12. These SSOs can supply seed for southern and central Florida.

Severe freezes made selection of fast growing, freeze resilient cloning candidates possible (Table 2). Collectively, 115 E. amplifolia cloning candidates were identified, with 35 entered in tests. Since E. amplifolia rooting percent is highly variable but typically half that is of E. grandis [10], many more candidates are needed for commercialization. Four C. torelliana cloning candidates have been identified and captured by tissue culture but have not been field tested. 
Table 1. Numbers of trees and accessions in Eucalyptus amplifolia and Corymbia torelliana genetic base populations and derived orchards by generation, name and orchard type, and year(s) of establishment adapted from [7].

\begin{tabular}{ccccccc}
\hline \multirow{2}{*}{ Generation } & \multirow{2}{*}{ Name-Orchard Type } & Year(s) & \multicolumn{2}{c}{ Base Population } & \multicolumn{2}{c}{ Orchard } \\
\cline { 3 - 7 } & & Trees & Accessions & Trees & Accessions \\
\hline & AO92-SSO & 1992 & 1685 & 109 & 139 & 106 \\
\hline 1 & AO99-SSO & 1999 & 1638 & 59 & 40 & 22 \\
\hline 2 & AO03-SSO & 2003 & $>294$ & 45 & 45 & 24 \\
\hline 2 & AO10-SSO & 2010 & 605 & 44 & $>6$ & $>6$ \\
\hline 2 & AO13-CSO & $2013-2016$ & 508 & 48 & 38 & 21 \\
\hline 2 & & C. torelliana & & & \\
\hline 1 & TO08-SSO & 2008 & 960 & 29 & 69 & 25 \\
\hline 2 & TO12-SSO & 2012 & 2040 & 66 & 83 & 47 \\
\hline
\end{tabular}

Table 2. Numbers of Eucalyptus amplifolia and Corelliana torelliana clones selected, tested, and commercialized from [7].

\begin{tabular}{cccc}
\hline Species & Selected & Tested & Commercialized \\
\hline E. amplifolia & 115 & 35 & 1 \\
C. torelliana & 4 & 0 & 0 \\
\hline
\end{tabular}

A novel method has been used to propagate E. amplifolia commercial cultivar A1 because it does not respond to rooting hormones and its tip cuttings fail to root. Several weeks after cutting a clone down in March-April at a height of $\sim 0.75 \mathrm{~m}$, when stump shoots are $\sim 1 \mathrm{~m}$ long, 3-node cuttings are cut from the firm sections of the shoots. The cuttings are then completely submerged in a solution of seaweed extract (dry concentrate from Arcadian Seaplants at 5000 ppm in water) for 1-2 h, followed by double wounding of the basal segments to promote more robust root development, then insertion into a rooting mix of $45 \%$ perlite and $55 \%$ pine bark amended with controlled release fertilizer, cutting the leaves on the upper two nodes in half to reduce water loss, and, after rooting under mist, being moved to 50\% shade and fertilized weekly with water soluble 20-20-20 at half rate.

Cultivar A1 has very good form with a wider crown than most E. amplifolia, making it well suited for ornamental use (Figure 2). Its relatively long retention of juvenile foliage contributes to a very rapid growth rate. It has excellent cold-hardiness, withstanding temperatures to $-9{ }^{\circ} \mathrm{C}$ when established, and also is blue gum chalcid (Leptocybe invasa) resistant. Seedlings grown from A1 seed have also been chalcid resistant and have exceptional form.

BVs have been developed for five E. amplifolia and five C. torelliana traits that are important for best deployment of genotypes (Table 3). The numbers of progeny tests contributing to these BVs were 15 in Florida and the southeastern USA for E. amplifolia and seven in Florida for C. torelliana. All test data were first processed in SAS version 9.4 (Copyright@ 2002-2012 by SAS Institute Inc., Cary, NC, USA). For each continuous trait, an analysis was run by test to determine if there were any heritability for the trait. For those tests with heritability, the data were standardized by the square root of the progeny variance, making the standardized progeny variance equal 1. Data were then assembled and analyzed in ASREML ver. 4.1, 2014 [11]. For binary traits, the data were run in ASREML using a logit link function. The results from the logit analysis were then back transformed into percentages. For E. amplifolia, the gains for continuous traits were calculated against the overall mean, and the binary trait gains were calculated as though the incidence were $50 \%$. For C. torelliana, the gains for all traits were calculated against the overall least square 
mean performance of the TO08 orchard trees. The general formula for gain calculations in percentage was $100 *($ (prediction + population mean $)-$ checklot mean)/checklot mean.

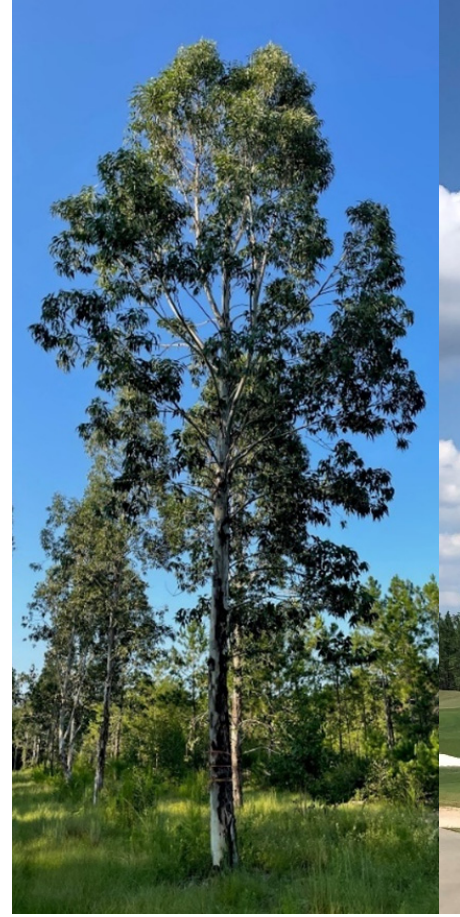

(a)

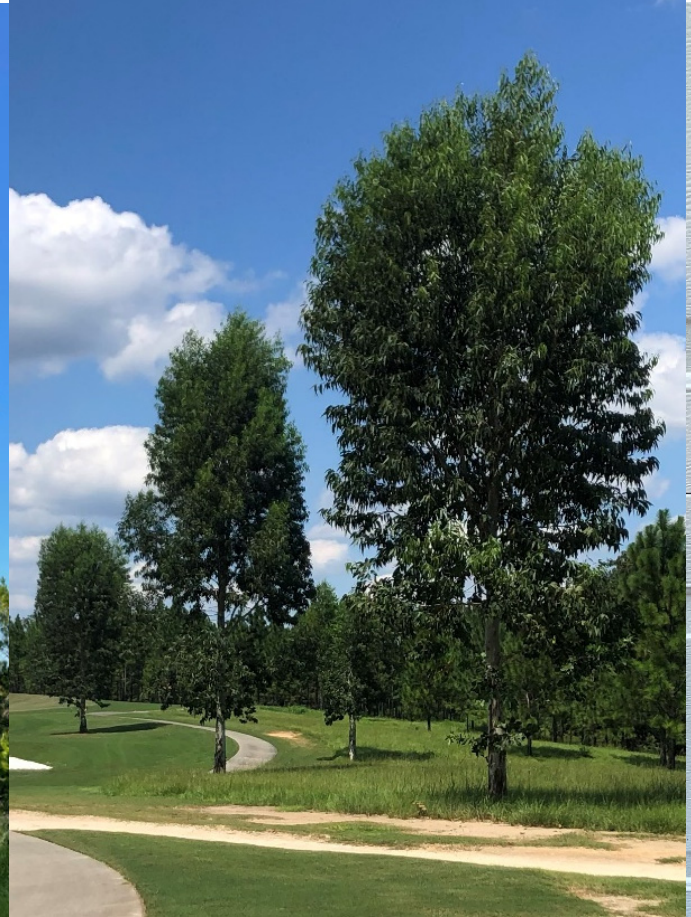

(b)

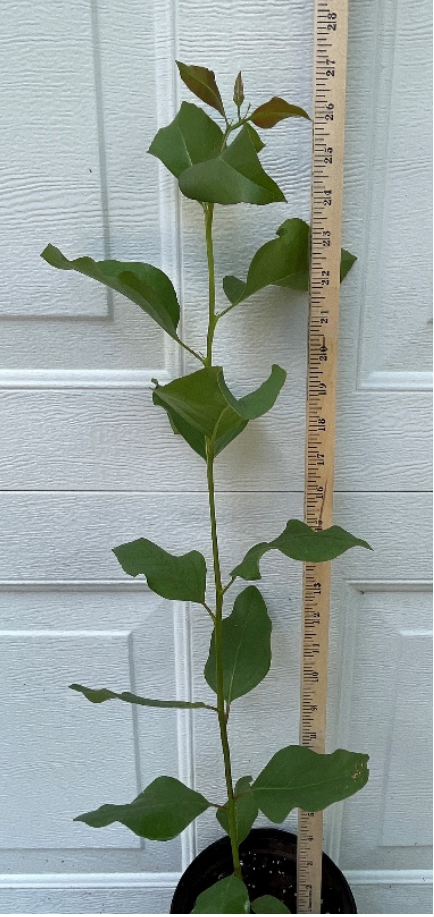

(c)

Figure 2. Cultivar $\mathrm{A} 1$ in seed orchard $\mathrm{AO} 13$ at seven years (a), 6-year-old $\mathrm{A} 1$ clones (b), and 4-monthold A1 open-pollinated seedling (c).

Table 3. Number of accessions assessed and mean, maximum, and minimum breeding values ( $\%,+$ or - indicates best, where $\%$ indicates positive or negative percentage deviation from the checklot least square mean) for Eucalyptus amplifolia and Corymbia torelliana by trait.

\begin{tabular}{ccccc}
\hline Trait & No. of Accessions & Mean & Maximum & Minimum \\
\hline \multicolumn{5}{c}{ E. amplifolia $(407$ accessions) } \\
\hline Tree Basal Area (+) & 320 & 1.1 & 32.4 & -36.1 \\
\hline Plot Basal Area (+) & 56 & 0.7 & 31.7 & -35.9 \\
\hline Stem Quality (-) & 308 & -0.4 & -30.9 & 258 \\
\hline Freeze Resilience (-) & 117 & 0.6 & -19.1 & 27.2 \\
\hline Chalcid Resistance (-) & 56 & -4.4 & -44.3 & 74.2 \\
\hline & C. torelliana (303 accessions) & & \\
\hline Tree Basal Area (+) & 296 & 1.7 & 12.1 & -10.7 \\
\hline Flowering (+) & 155 & 0.1 & 9.9 & -7.4 \\
\hline Stem Quality (-) & 300 & 3.7 & -11.8 & 26.8 \\
\hline Freeze Resilience (-) & 194 & -26.8 & -87.6 & 132.2 \\
\hline Pest Resistance (-) & 69 & 1.8 & -20.1 & 31.3 \\
\hline
\end{tabular}

Collectively, these BVs guide the selection of genotypes for individual applications. In Tree Basal Area and Plot Basal Area, which incorporate survival, BVs indicate individual tree size and per ha productivity, respectively. Regarding Stem Quality, on a $1=$ good to $5=$ poor scale, and Freeze Resilience, on a similar scale, BVs rate tree form and freeze 
tolerance and/or ability to regrow vigorously afterwards, respectively. As for Chalcid Resistance and Pest Resistance, both on $0=$ no incidence or $1=$ infected scale, BVs reflect relative resistance to critical pests. C. torelliana's Flowering BV assesses early flowering.

\section{Potential Uses}

Market opportunities in Florida for E. amplifolia and C. torelliana wood are now limited but could expand. Near existing pulp mills, specialty pulps may utilize eucalypts, but the hardwood pulpwood market forecast in the 1970s [1] has become a more local mulchwood market [5]. As cypress mulchwood availability decreases, more eucalypt wood may replace it.

Many wood markets for eucalypts, such as MDF, are undeveloped in Florida. In preliminary testing of their suitability for MDF, genetic variation between and particularly within E. amplifolia and C. torelliana affected their MDF potential [12]. These two studies of factors (wood characteristics, refining system, and resin system) influencing their suitability found that log specific gravity (SG), fines, MDF SG, and fiber length were most influential. A study using $4 \%$ phenol-formaldehyde resin detected some variation between species, considerable variation within species, minor variation within a tree, and some influence of basic wood characteristics. The second study involving the "best" genotype of each species and three resins concluded that certain genotypes may be suitable and that resin type and rate and percentage of fines influenced MDF properties. Refining and MDF-making aspects have such major impacts on MDF properties that specific processing requirements may be needed to optimize MDF production from E. amplifolia and C. torelliana genotypes. E. amplifolia may also be suitable for wood-cement boards, plywood, and oriented strand board [13-15].

Eucalyptus energywood uses have been demonstrated [16]. Eucalyptus has been considered as a feedstock for energy generation at pulp mills in Florida, and it has potential for use in biorefineries associated with pulp mills [17]. Eucalyptus has been proposed as the primary feedstock for stand-alone biomass power plants in Florida [18].

Eucalyptus amplifolia and C. torelliana have shown promise as biochar feedstocks and for sequestering carbon. The biochar of both species compares favorably with the commercial Polchar made from oak trees in Europe (Table 4). Biochar production in southern Florida may foster planting of the more dense C. torelliana (Table 5).

Table 4. Properties of biochar made from Florida C. torelliana and E. amplifolia trees with Polchar biochar (adapted from [19]).

\begin{tabular}{cccc}
\hline Property & C. torelliana & E. amplifolia & Polchar Biochar \\
\hline Recalcitrant Carbon * $\%)$ & 71.6 & 70.8 & 67.6 \\
\hline $\mathrm{pH}$ & 10.4 & 11.1 & 8.2 \\
\hline EC $(\mathrm{mmhos} / \mathrm{cm})$ & 1.76 & 3.88 & 3.33 \\
\hline Water Holding $(\mathrm{mL} / 100 \mathrm{~g})$ & 78.8 & 69.0 & 43.4 \\
\hline Carbonate Value $(\%)$ & 2.5 & 16.7 & - \\
\hline${ }^{*}$ Estimated at $80 \%$ of fixed carbon on a dry ash-free basis. & &
\end{tabular}

* Estimated at $80 \%$ of fixed carbon on a dry ash-free basis.

E. amplifolia is suitable for biofuel and bioenergy production. Its major wood chemicals in are lignin, glucan, and xylan [20]. For ethanol and methanol production, certain wood properties are typically favored: higher wood density, lower moisture content, and higher extractives content [21]. There were differences between and within E. amplifolia and C. torelliana for some of these properties based on limited genotypes and ages (Table 5), which suggests that clonal deployment would be advantageous in producing energy products. Similar variation in refined fiber characteristics also emphasized the importance of genetic variation in making other products. 
Table 5. Basal log specific gravity $\left(\mathrm{kg} / \mathrm{m}^{3}\right)$, moisture content $(\%)$, batch fines $(\%), \mathrm{pH}$, and fiber length (mm) of Florida-grown E. amplifolia and C. torelliana adapted from [20].

\begin{tabular}{|c|c|c|c|c|c|c|}
\hline Genotype & $\begin{array}{l}\text { No. of } \\
\text { Trees }\end{array}$ & $\begin{array}{l}\text { Specific } \\
\text { Gravity }\end{array}$ & $\begin{array}{l}\text { Moisture } \\
\text { Content }\end{array}$ & Fines & $\mathrm{pH}$ & $\begin{array}{c}\text { Fiber } \\
\text { Length }\end{array}$ \\
\hline \multicolumn{7}{|c|}{ 8.3-year-old E. amplifolia } \\
\hline 4 progenies & 4 & 508 & 108 & 59.5 & 3.97 & \\
\hline 4836 & 1 & 527 & 107 & 53.1 & 3.89 & - \\
\hline 4843 & 1 & 469 & 115 & 53.5 & 3.89 & - \\
\hline 4853 & 1 & 506 & 109 & 70.7 & - & - \\
\hline 4875 & 1 & 529 & 88 & 60.5 & 4.11 & 0.502 \\
\hline \multicolumn{7}{|c|}{ 15-year-old C. torelliana } \\
\hline 4 trees & 4 & 526 & 101 & 50.0 & 4.20 & \\
\hline$?$ & 1 & 526 & 80 & 48.6 & 4.17 & - \\
\hline$?$ & 1 & 610 & 98 & 52.6 & 4.20 & - \\
\hline$?$ & 1 & 555 & 94 & 37.1 & 4.23 & 0.472 \\
\hline$?$ & 1 & 411 & 131 & 61.5 & 4.21 & - \\
\hline
\end{tabular}

Cost-effective capture of the many silvichemicals in Eucalyptus species is critical to their commercial use. Steam pretreatment of wood chips of E. amplifolia and C. torelliana yielded a multitude of components in condensate extracts but no compound was in sufficient quantity to make separation and recovery commercially viable [20]. Capturing them as incidental byproducts of other wood processing may be an option.

SRWC systems maximize productivity for the above uses [11,22-31]. Due to propagation ease, rapid growth, tolerance to high stand density, response to intensive culture, and coppicing, E. amplifolia can produce up to 67 green $\mathrm{mt} \mathrm{ha}^{-1} \mathrm{yr}^{-1}$ in multiple SRWC rotations as short as three years. It is very responsive to soil amendments, vegetation control, and irrigation.

Eucalyptus amplifolia and C. torelliana also have other uses. E. amplifolia Cultivar A1 has been planted in multiple southern Georgia (USDA Zone 8b) locations, primarily for ornamental purposes in yards and at a local golf course (Figure 1). E. amplifolia is also being considered for windbreaks around citrus orchards to reduce the spread of disease and insects and to provide cold protection in the winter. Since E. amplifolia loses its lower limbs when mature, double row windbreaks using another low growing evergreen species to block low level wind provide the best protection. Another potential use is to interplant E. amplifolia in citrus orchards, especially those involving satsuma mandarins, to provide up to $30 \%$ dappled shade that reduces sunburn injury on fruit, to perhaps confuse insects that feed on citrus trees, and also to provide some frost protection in more cold frequent areas like southern Georgia.

One of the E. amplifolia uses in Australia is for honey production [32] because it flowers prolifically in late winter and early spring when other flowers are not available. C. torelliana produces abundant flowers four times a year. With the significant reduction in the number of citrus trees in Florida due to citrus greening, beekeepers are seeking other plants to support their honey bees. Other uses include tall visual barriers and sound barriers along highways.

While both Eucalyptus amplifolia and C. torelliana can be used in windbreaks [11,33-38], C. torelliana has been more widely planted around citrus groves and vegetable fields in central and southern Florida (Figure 3). Since 2010, PRCN has grown potted C. torelliana seedlings from TO08 for agricultural, residential, and commercial windbreaks and privacy screening. TO08 seed are dried, sieved, purified, weighed, cataloged, packed in coin envelopes, and then stored in airtight containers at $4.4-5.5{ }^{\circ} \mathrm{C}$ with silica gel desiccant. Seed is taken from cold storage and germinated in $5 \times 10 \mathrm{~cm}$ Ellepots in 45 cell trays in a 
greenhouse. Germination/selection rate for stored seeds averages about $72 \%$. About $15-\mathrm{cm}-$ tall seedlings are transplanted into $15 \mathrm{~cm}$ nursery pots to grow to $45-60 \mathrm{~cm}$ height outdoors.

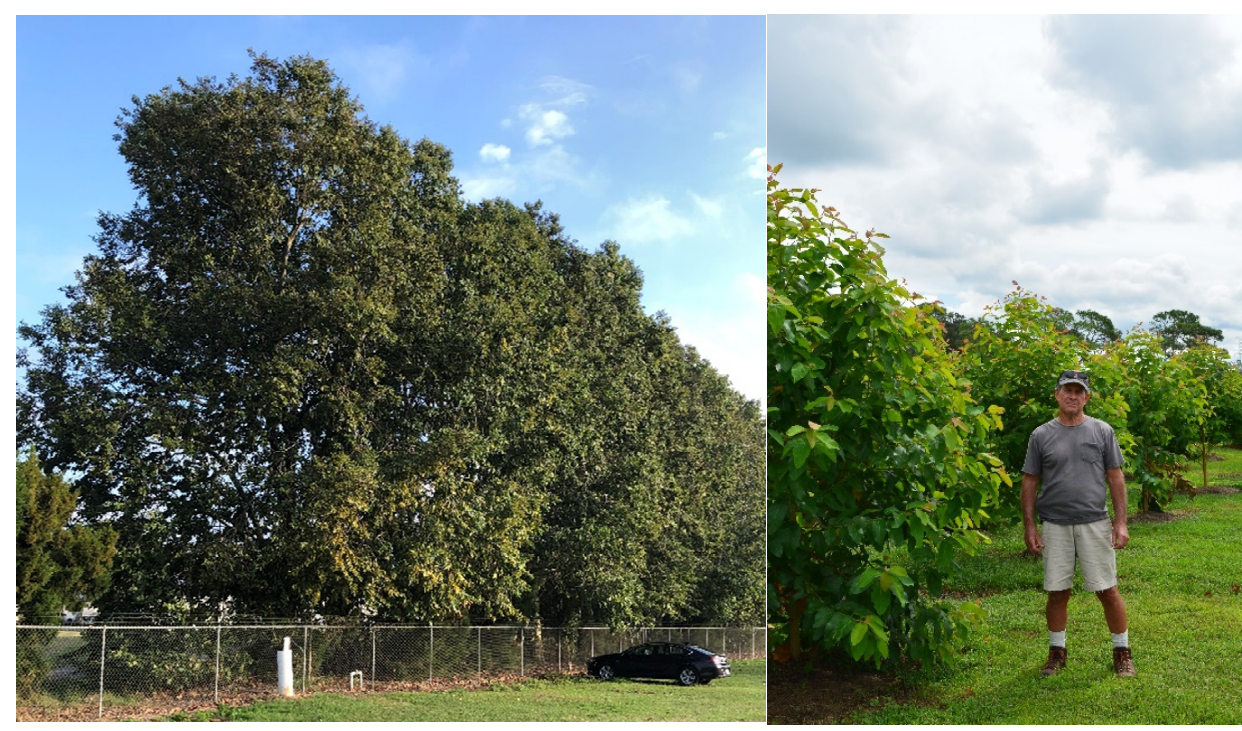

(a)

(b)

Figure 3. C. torelliana windbreaks in Florida using PRCN potted seedlings: 11-years-old near Frostproof (a) and 5-months-old near Plant City ((b), courtesy of S. Moss).

Two unpublished studies in Florida illustrate the performance of $C$. torelliana in windbreaks. In June 2012, two-row windbreaks consisting of E. grandis cultivars and C. torelliana progenies in adjacent staggered rows $2.4 \mathrm{~m}$ apart were established around two Rapid Infiltration Basins (RIB 2-3 and RIB 3-2) near Winter Garden. The trees were subsequently irrigated with reclaimed water and periodically measured. Carbon sequestration was estimated by applying equations for E. grandis in Brazil [39] and C. torelliana in Florida [40]. The cultivars were bigger in RIB 2-3 while the progenies were similar across the RIBs (Table 6). Consequently, at 16 months, the cultivars had higher sequestration in RIB 2-3, and sequestration by the progenies was basically the same in both RIBs, but not as high as the cultivars in RIB 2-3. Comparison of C. torelliana carbon sequestration with that of E. grandis in this windbreak study suggests that the typically higher wood density of $C$. torelliana (Table 5) may offset its somewhat slower growth compared to E. grandis.

Table 6. Average height $(\mathrm{m}), \mathrm{DBH}(\mathrm{cm})$, and carbon sequestration $(\mathrm{mt} / \mathrm{ha})$ at age 16 months of E. grandis cultivars and C. torelliana progenies in two-row windbreaks in RIBs 2-3 and 3-2.

\begin{tabular}{ccccc}
\hline & \multicolumn{2}{c}{ E. grandis Cultivars } & \multicolumn{2}{c}{ C. torelliana Progenies } \\
\cline { 2 - 5 } & $\mathbf{2 - 3}$ & $\mathbf{3 - 2}$ & $\mathbf{2 - 3}$ & $\mathbf{3 - 2}$ \\
\hline Height & 6.0 & 4.9 & 5.8 & 5.7 \\
\hline DBH & 8.2 & 7.2 & 6.4 & 6.7 \\
\hline Sequestration Above Ground & 0.83 & 0.51 & 0.64 & 0.68 \\
\hline Sequestration Below Ground & 0.09 & 0.05 & 0.13 & 0.14 \\
\hline Total Sequestration & 0.92 & 0.56 & 0.77 & 0.82 \\
\hline
\end{tabular}

The second windbreak study involved two windbreaks established in late March 2014 around a citrus grove near Clermont, Florida, following Roundup herbicide in mid-March. In the northern windbreak, seedlings of $C$. torelliana progeny 1-14 were planted in a single row at $1.5 \mathrm{~m}$ spacing, and in the double row southern windbreak at $2.4 \mathrm{~m}$ spacing, E. grandis cultivar G3 was established in the interior (north) row and C. torelliana progeny 1-14 in 
the staggered (1.2 m offset) exterior (south) row. The trees were subsequently irrigated for four years and measured through May 2020. At age 74 months, C. torelliana in a single row configuration was taller (12.6 vs. $10.8 \mathrm{~m})$ but had similar DBH (17.9 vs. $17.5 \mathrm{~cm})$ compared to its size in the 2-row configuration. In the double row southern windbreak, 1-14 seedlings in the exterior row were smaller than G3 in the interior row (10.8 vs. $24.1 \mathrm{~m}$ in height, 17.5 vs. $24.2 \mathrm{~cm}$ in $\mathrm{DBH}$ ), a relationship that makes this two species combination ideal for quickly reaching maximum windbreak height while maintaining full canopy closure from the ground up.

Eucalyptus amplifolia and C. torelliana may also be used for dendroremediation and weed suppression. For dendroremediation, E. amplifolia can be very effective [41-50]. Eucalyptus grandis and E. amplifolia progenies and Populus deltoides clones were evaluated for energywood production and dendroremediation of accumulated soil nitrogen (N) and phosphorus (P) in 27-month stand rotations at the Tallahassee, Florida, municipal waste spray field [50]. Eucalyptus grandis grows fastest and thus has the greatest potential nutrient capture, but E. amplifolia is more cold-hardy and appropriate in freeze-frequent areas. Eucalyptus is evergreen, an advantage for year-round nutrient and contaminant capture. Eucalyptus also regenerates effectively from stump sprouts (coppicing) following harvest, facilitating reproduction in short rotations optimizing both nutrient removal and energywood production. The highest biomass producing $P$. deltoides clone (110412) removed $215 \%$ of $\mathrm{N}$ and $615 \%$ of $\mathrm{P}$ effluent water inputs, indicating effectiveness in reducing soil nutrient concentrations and mitigating potential groundwater pollution. Eucalyptus amplifolia and E. grandis survived and grew very poorly as the result of below-normal winter freezing temperatures during the study period and were not evaluated for nutrient removal. However, this discriminating event provided an opportunity to assess potential E. amplifolia progeny recovery. Tree height growth indicated greater recovery for progeny 5050 and 5108 than others tested. Eucalypts may be "bridge crops" to convert lands infested with invasive species to agricultural uses [51]. Planting trees at high density results in canopy closure in a few months, shading out understory plants.

\section{Research Needs}

Genetic and silvicultural improvements with E. amplifolia and C. torelliana have dramatically improved their productivity, but still more progress may be made through research in freeze resilience, growth, coppicing, pest resistance, and propagation. While advanced generation breeding could produce more advanced SSOs and CSOs to improve these traits, significant improvements may accrue from clonal selection and testing.

In collaboration with Camcore, North Carolina State University, over 1.8 million seed were collected from the AO03, AO10, and AO13 seed orchards in November 2019. A set of 38 family seedlots will be used to establish progeny tests by 15-20 Camcore members in 11 countries (Argentina, Brazil, Chile, Colombia, Ghana, Sierra Leone, Indonesia, Kenya, Mexico, South Africa, Uruguay). In March 2020, pollen was collected from 13 E. amplifolia clones for a collaborative eucalyptus hybridization project that will attempt to produce more than 20 different hybrid combinations in total: E. globulus $x$ E. amplifolia and E. grandis $x$ E. amplifolia, as well as a three-way hybrid, (E. grandis $x$ E.nitens) $x$ E. amplifolia.

For proven clones, economical and rapid propagation is necessary. Current vegetative propagules are more expensive than seedlings. Florida's seasonal planting schedule further necessitates the need for periodic rapid buildups of propagules.

Silvicultural enhancements are needed because of the infertility, low $\mathrm{pH}$, and low organic matter of many available planting sites. Appropriate environmentally friendly amendments such as organic fertilizers and biochar need study and documentation. Application of available wastewaters to plantations needs to be commercialized. Growth and yield models reflecting genetic and silvicultural improvements are needed.

Expanded markets for E. amplifolia and C. torelliana in Florida may depend on energy project development and technology improvement. The current market for mulchwood is met by existing plantations, but the mulchwood market could expand as cypress availability 
decreases. Pellet plants, biomass-fueled utility plants, and especially biochar production facilities could significantly increase demand. Improvements in biomass conversion at pulpmills and stand-alone biorefineries would also increase demand.

\section{Conclusions}

Collaboration over 40 years by many individuals and organizations has developed E. amplifolia and C. torelliana with the necessary growth, freeze resilience, and site tolerance for peninsular Florida and similar areas. For central Florida northward into southern Georgia, Alabama, Mississippi, Louisiana, and Texas, superior E. amplifolia seed, based on $\mathrm{BVs}$, is available from SSOs and a CSO. For southern and central Florida, C. torelliana seed, also based on BVs, is available from 1st and 2nd generation SSOs. While mulchwood is the current market for E. amplifolia and C. torelliana is used for windbreaks, these species may be used for multiple products. Using SRWC systems, their productivities are high and will be required to meet feedstock demands for energywood markets. Collaborative genetic improvement continues to increase growth, freeze resilience, and pest resistance, and thus realize the many attributes of E. amplifolia and C. torelliana.

Author Contributions: Conceptualization, D.L.R., P.J.M. and G.R.H.; methodology, D.L.R., D.A.H., M.A.C., E.L., P.C.R., K.W.F., P.J.M., R.J. and G.R.H.; software, D.L.R., D.A.H., K.W.F., P.J.M. and G.R.H.; validation, D.L.R., D.A.H., M.A.C., E.L., P.C.R., K.W.F., P.J.M., R.J. and G.R.H.; formal analysis, investigation, D.L.R., D.A.H., M.A.C., E.L., P.C.R., K.W.F., P.J.M., R.J. and G.R.H.; resources, D.L.R., D.A.H., M.A.C., E.L., P.C.R., K.W.F., P.J.M., R.J. and G.R.H.; data curation, D.L.R., D.A.H., M.A.C., E.L., P.C.R., K.W.F., P.J.M., R.J. and G.R.H.; writing—original draft preparation, D.L.R., D.A.H., M.A.C., E.L., P.C.R., K.W.F., P.J.M. and G.R.H.; writing—review and editing, D.L.R., D.A.H., M.A.C., E.L., P.C.R., K.W.F., P.J.M., R.J. and G.R.H.; visualization, D.L.R., D.A.H. and M.A.C.; supervision, D.L.R., M.A.C., P.C.R., K.W.F., P.J.M. and G.R.H.; project administration, D.L.R., D.A.H., M.A.C., P.C.R., P.J.M., R.J. and G.R.H.; funding acquisition, D.L.R., M.A.C., P.C.R., P.J.M. and G.R.H. All authors have read and agreed to the published version of the manuscript.

Funding: Numerous other institutions and companies also contributed to the current status of E. amplifolia and C. torelliana in Florida through financial support and/or in-kind collaboration: the Florida Division of Forestry, the Short Rotation Woody Crops Program of the US Department of Energy, the Gas Research Institute, the USDA Forest Service and its Forest Products Laboratory, the Florida Institute of Phosphate Research, Southeastern Regional Biomass Energy Program, USDASARE, Sumter County, UF's Center for Biomass Energy Programs, School of Forest Resources and Conservation, and North Florida Research and Education Center, Buckeye Technology Florida, Natural Resource Planning Services, Mosaic, and Terviva.

Institutional Review Board Statement: Not applicable.

Informed Consent Statement: This research did not involve humans.

Data Availability Statement: Restrictions apply to the availability of these data. Data were obtained from several coauthors and may be available from the coauthors with their permission.

Acknowledgments: The authors gratefully acknowledge recent in-kind support provided by Green Carbon Solutions, UF's Indian River Research and Education Center, Loch Laurel Nursery, Florida Grown Specialties, Evans Properties, Camcore, and S and R Moss.

Conflicts of Interest: Authors declare no conflict of interests.

\section{References}

1. Geary, T.F.; Meskimen, G.F; Franklin, E.C. Growing Eucalypts in Florida for Industrial Wood Production; Tech. Rep. SE-23; USDA Forest Service Southeastern Forest Experiment Station General: Asheville, NC, USA, 1983.

2. Rockwood, D.L.; Kellison, R.C.; Franklin, E.C.; Meskimen, G.F. Operational advanced generation improvement programs for minor species in the South. South. Coop. Ser. Bull. 1986, 309, 27-37.

3. Kellison, R.; Lea, R.; Marsh, P. Introduction of Eucalyptus spp. into the United States with Special Emphasis on the Southern United States. Int. J. For. Res. 2013, 2013. Available online: https://www.hindawi.com/journals/ijfr/2013/189393 (accessed on 21 November 2021). 
4. Meskimen, G.F.; Rockwood, D.L.; Reddy, K.V. Development of Eucalyptus clones for a summer rainfall environment with periodic severe frosts. New For. 1987, 1, 197-205. [CrossRef]

5. Rockwood, D.L.; Peter, G.F. Eucalyptus and Corymbia Species for Mulchwood, Pulpwood, Energywood, Bioproducts, Windbreaks, and/or Phytoremediation, Florida Cooperative Extension Service Circular 1194; UF/IFAS Extension, University of Florida: Gainesville, FL, USA, 2018

6. Rockwood, D.L. History and Status of Eucalyptus Improvement in Florida. Int. J. For. Res. 2012, 2012. Available online: http:/ / www.hindawi.com/journals/ijfr/2012/607879/s (accessed on 21 November 2021).

7. Rockwood, D.L. History and status of Eucalyptus improvement in Florida: 2020. In New Perspectives in Agriculture and Crop Science; Naik, A., Ayeni, L.S., Eds.; New Perspectives in Agriculture and Crop Science I B P International (bookpi.org); Book Publisher International: Chinsurah, India, 2020; Volume 3.

8. Rockwood, D.L.; Reddy, K.V.; Warrag, E.I.; Comer, C.W. Development of Eucalyptus amplifolia for woody biomass production Aust. For. Res. 1987, 17, 173-1178.

9. Rockwood, D.L.; Pathak, N.N.; Satapathy, P.C.; Warrag, E.E. Genetic improvement of Eucalyptus amplifolia for frost-frequent areas Aust. For. 1991, 54, 212-218. [CrossRef]

10. Rockwood, D.L.; Dinus, R.J.; Kramer, J.M. Genetic variation for rooting, growth, frost hardiness, and wood, fiber, and pulping properties in Florida-grown Eucalyptus amplifolia. In Proceedings of the 22nd Southern Forest Tree Improvement Conference, Atlanta, GA, USA, 14-17 June 1993.

11. Gilmour, A.R.; Gogel, B.J.; Cullis, B.R.; Welham, S.J.; Thompson, R. ASReml User Guide Release 4.1 Structural Specification; VSN International Ltd.: Hemel Hempstead, UK, 2014.

12. Rockwood, D.L.; Winandy, J.E. Resin and Pressing Requirements for Making MDF from Florida-Grown Eucalyptus Grandis, E. Amplifolia, Corymbia Torelliana, and Cottonwood. In Proceedings of the Forest Products Society 62nd International Convention, St. Louis, MO, USA, 22-24 June 2008; p. 14.

13. Setsuo, I.; Mendes, L.M.; Saldanha, L.K.; dos Santos, J.C. Use of Eucalyptus wood for oriented strand board (OSB) manufacturing Cerne 2004, 10, 46-52.

14. Campos, C.I.; Lahr, F.A.R. Production and characterization of MDF using eucalyptus fibers and castor oil-based polyurethane resin. J. Mater. Res. 2004, 7, 421-425. [CrossRef]

15. Ashori, A.; Tabarsa, T.; Azizi, K.; Mirzabeygi, R. Woodwool cement board using mixture of eucalypt and poplar. Ind. Crops Prod. 2011, 34, 1146-1149. [CrossRef]

16. Segrest, S.A.; Rockwood, D.L.; Stricker, J.A.; Green, A.E.S. Biomass Cofiring with Coal at Lakeland Utilities; Southeastern Regional Biomass Energy Program Publication: Muscle Shoals, AL, USA, 1998.

17. Martin-Sampedro, R.; Eugenio, M.E.; Revilla, R.; Martin, J.A.; Villar, J.C. Integration of Kraft pulping on a forest biorefinery by the addition of steam explosion pretreatment. BioResources 2011, 6, 513-528. [CrossRef]

18. Soberg, M.U.S. EcoGen Plans 60 MW Florida Biomass Power Plant. Biomass Power E Thermal. Available online: http:// biomassmagazine.com/articles/5828/u-s-ecogen-plans-60-mw-florida-biomass-power-plant (accessed on 10 September 2011).

19. Rockwood, D.L.; Ellis, M.F.; Liu, R.; Zhao, F.; Fabbro, K.W.; He, Z.; Derbowka, D.R. Forest Trees for Biochar and Carbon Sequestration: Production and Benefits. In Applications of Biochar for Environmental Safety; Abdelhafez, A., Abbas, M., Eds.; IntechOpen: London, UK, 2020.

20. Rockwood, D.L.; Rudie, A.W.; Ralph, S.A.; Zhu, J.Y.; Winandy, J.E. Energy product options for Eucalyptus species grown as short rotation woody crops. Int. J. Mol. Sci. 2008, 9, 1361-1378. [CrossRef]

21. Rockwood, D.L.; Squillace, A.E. Increasing Alcohol Production from Wood by Utilizing Genetic Variation in Wood Characteristics. In Proceedings of the TAPPI Annual Meeting, St. Paul, MN, USA, 21-25 June 1981; pp. 307-316.

22. Reddy, K.V.; Rockwood, D.L.; Comer, C.W.; Meskimen, G.F. Genetic improvement of Eucalyptus grandis for biomass production in Florida. Biomass Energy Dev. 1985, 103-110.

23. Rockwood, D.L.; Comer, C.W.; Conde, L.F. Final Report: Energy and Chemicals from Woody Species in Florida; Tech. Rep. ORNL/Sub/81 9050/1; Oak Ridge National Laboratory: Oak Ridge, TN, USA, 1983.

24. Rockwood, D.L.; Dippon, D.R.; Lesney, M.S. Woody Species for Biomass Production in Florida; Final Report ORNL/Sub/81 9050/7; Oak Ridge National Laboratory: Oak Ridge, TN, USA, 1988.

25. Rockwood, D.L.; Comer, C.W.; Dippon, D.R.; Huffman, J.B.; Riekerk, H.; Wang, S. Current status of woody biomass production research in Florida. Soil Crop Sci. Soc. Fla. 1983, 42, 19-27.

26. Dippon, D.R.; Rockwood, D.L.; Comer, C.W. Cost sensitivity analyses of Eucalyptus woody biomass systems. Biomass Energy Dev. 1958, 143-156.

27. Rockwood, D.L. Development of woody biomass cultural systems for Florida. Biomass Energy Dev. 1985, 85-94.

28. Rockwood, D.L.; Pisano, S.M.; McConnell, W.V. Superior Cottonwood and Eucalyptus Clones for Biomass Production in Waste Bioremediation Systems. In Proceedings of the 7th National Bioenergy Conference, Nashville, TN, USA, 15-20 September 1996; pp. 254-261.

29. Rockwood, D.L.; Carter, D.R.; Langholtz, M.H.; Stricker, J.A. Eucalyptus and Populus short rotation woody crops for phosphate mined lands in Florida USA. Biomass Bioenergy 2006, 30, 728-734. [CrossRef]

30. Langholtz, M.; Carter, D.R.; Rockwood, D.L.; Alavalapati, J.R.R. The economic feasibility of reclaiming phosphate mined lands with short-rotation woody crops in Florida. J. For. Econ. 2007, 12, 237-249. [CrossRef] 
31. Rockwood, D.L.; Carter, D.R.; Stricker, J.A. Commercial Tree Crops on Phosphate Mined Lands; Florida Institute of Phosphate Research, FIPR Publication: Bartow, FL, USA, 2008.

32. Clemson, A.A. Honey, and pollen plants of N.S.W. 64. Cabbage gum (Eucalyptus amplifolia). Australas. Beekeeper 1980, 81, 176-179.

33. Tamang, B.; Andreu, M.G.; Rockwood, D.L. Sustaining farm productivity through windbreaks. APA News 2008, 33, 7-9.

34. Andreu, M.G.; Tamang, B.; Friedman, M.H.; Rockwood, D.L. The Benefits of Windbreaks for Florida Growers; Tech. Rep. FOR192; UF/IFAS Extension, University of Florida: Gainesville, FL, USA, 2008.

35. Andreu, M.G.; Tamang, B.; Rockwood, D.L.; Friedman, M.H. Potential Woody Species and Species Attributes for Windbreaks in Florida; Tech. Rep. FOR224; UF/IFAS Extension, University of Florida: Gainesville, FL, USA, 2009.

36. Tamang, B.; Andreu, M.G.; Friedman, M.H.; Rockwood, D.L. Windbreak Designs and Planting for Florida Agricultural Fields; Tech. Rep. FOR227; UF/IFAS Extension, University of Florida: Gainesville, FL, USA, 2009.

37. Tamang, B.; Andreu, M.G.; Friedman, M.H.; Rockwood, D.L. Management of Field Windbreaks; Tech. Rep. FOR288; UF/IFAS Extension, University of Florida: Gainesville, FL, USA, 2009.

38. Tamang, B.; Andreu, M.G.; Rockwood, D.L. Microclimate patterns on the leeside of single-row tree windbreaks during different weather conditions in Florida farms: Implications for improved crop production. Agrofor. Syst. 2010, 79, 111-122. [CrossRef]

39. Campoe, O.C.; Stape, J.L.; Laclau, J.-P.; Marsden, C.; Nouvellon, Y. Stand-level patterns of carbon fluxes and partitioning in a Eucalyptus grandis plantation across a gradient of productivity in Sao Paulo, Brazil. Tree Physiol. 2012, 32, 696-706. [CrossRef]

40. Tamang, B.; Andreu, M.G.; Staudhammer, C.L.; Rockwood, D.L.; Jose, S. Equations for estimating aboveground biomass of cadaghi (Corymbia torelliana) trees in farm windbreaks. Agrofor. Syst. 2012, 86, 255-266. [CrossRef]

41. Rockwood, D.L.; Naidu, C.V.; Carter, D.R.; Rahmani, M.; Spriggs, T.A.; Lin, C.; Alker, G.R.; Isebrands, J.G.; Segrest, S.A. Shortrotation woody crops and phytoremediation: Opportunities for agroforestry? In New Vistas in Agroforestry, a Compendium for the 1st World Congress of Agroforestry; Nair, P.K.R., Rao, M.R., Buck, L.E., Eds.; Kluwer Academic Publishers: Dordrecht, The Netherlands, 2004; pp. 51-63.

42. Rockwood, D.L.; Snyder, G.H.; Sprinkle, R.R. Woody Biomass Production in Wastewater Recycling Systems; Tech. Rep. 91327; Southeastern Regional Biomass Energy Program Publication: Muscle Shoals, AL, USA, 1995.

43. Rockwood, D.L.; Snyder, G.H.; Sprinkle, R.R. Woody biomass production in waste recycling systems. In Proceedings of the 6th National Bioenergy Conference, Reno, NV, USA, 2-6 October 1994; pp. 351-358.

44. Rockwood, D.L.; Snyder, G.H.; Sprinkle, R.R.; Leavell, A. Stormwater remediation by tree crops in Florida. In Proceedings of the 4th Biennial Stormwater Research Conference, Clearwater, FL, USA, 18-20 October 1995; pp. 309-319.

45. Rockwood, D.L.; Ma, L.Q.; Alker, G.R.; Tu, C.; Cardellino, R.W. Phytoremediation of Contaminated Sites Using Woody Biomass; Tech. Rep.; The Florida Center for Solid and Hazardous Waste Management: Tallahassee, FL, USA, 2001.

46. Abichou, T.; Musagasa, J.; Yuan, L.; Chanton, J.; Tawfiq, K.; Rockwood, D.; Licht, L. Field Performance of Alternative Landfill Covers Vegetated with Cottonwood and Eucalyptus Trees. Int. J. Phytoremediat. 2012, 14, 47-60. [CrossRef] [PubMed]

47. Rockwood, D.; Becker, B.; Ozores-Hampton, M. Municipal Solid Waste Compost Benefits on Short Rotation Woody Crops. Compos. Sci. Util. 2012, 20, 67-72. [CrossRef]

48. Rockwood, D.L.; Isebrands, J.G.; Minogue, P.J. Phytoremediation trees for biofuel. In Biofuel Crops; Singh, B., Ed.; CABI: Wallingford, UK, 2012; Chapter 22.

49. Summer, K.; Reichelt-Brushett, A. Trace element contaminant uptake in phytocap vegetation and implications for koala habitat, Lismore, Australia. Environ. Sci. Pollut. Res. 2018, 25, 24281-24292. [CrossRef] [PubMed]

50. Minogue, P.J.; Miwa, M.; Rockwood, D.L.; Mackowiak, C.L. Removal of Nitrogen and Phosphorus Byeucalyptusandpopulusat a Tertiary Treated Municipal Wastewater Sprayfield. Int. J. Phytoremediat. 2012, 14, 1010-1023. [CrossRef]

51. Tamang, B.; Rockwood, D.L.; Langholtz, M.; Maehr, E.; Becker, B.; Segrest, S. Fast-growing trees for cogongrass (Imperata cylindrica) suppression and enhanced colonization of understory plant species on a phosphate-mine clay settling area. Ecol. Eng. 2008, 32, 329-336. [CrossRef] 